\title{
The Emergence and Development of Ethnic Strongholds and Frontiers of Collective Violence in Jos, Nigeria
}

\author{
Kingsley L. Madueke
}

\begin{abstract}
Contestations over indigene rights and political representation resulted in Christian-Muslim riots in the Nigerian city of Jos where, between 2001 and 2010, over 5,000 people were killed. This study complements existing literature on the spatial dimension of violence by focusing on how Jos's neighborhoods were transformed from everyday residential areas to spaces of ethnic differentiation and violence. It employs an ethnographic study to map the emergence and development of ethnic strongholds and frontiers, two kinds of socio-spatial settings conceptualized to help explain the spread and patterns of violence across Jos's neighborhoods.
\end{abstract}

Résumé: Les contestations sur les droits des peuples autochtones et leur représentation politique ont entraîné des émeutes entre chrétiens et musulmans dans la ville de Jos, Niger, où entre 2001 et 2010, plus de 5000 personnes ont été tuées. Cette étude complète la littérature existante sur la dimension spatiale de la violence en mettant l'accent sur la transformation des quartiers de Jos, zones résidentielles de vie quotidienne, en espaces de différenciation ethnique et de violence. Cet article utilise une étude ethnographique pour cartographier l'émergence et le développement de bastions ethniques et de frontières, deux genres de cadres socio-spatiaux conçus pour expliquer les différents scénarios de la violence et leurs propagations dans les quartiers de Jos.

African Studies Review, Volume 62, Number 4 (December 2019), pp. 6-30

Kingsley L. Madueke has a PhD from the department of Political Science, University of Amsterdam. He was a Marie Curie Early State Researcher between 2014 and 2015. His research interests include violent extremism, ethnic violence, political instability, radicalization and security and regional studies. E-mail: kingsmadueke@gmail.com

(c) African Studies Association, 2019. This is an Open Access article, distributed under the terms of the Creative Commons Attribution licence (http://creativecommons. org/licenses/by-ncnd/4.0/), which permits unrestricted re-use, distribution, and reproduction in any medium, provided the original work is properly cited. doi:10.1017/asr.2018.115 
Resumo: Os protestos em defesa dos direitos e da representação política dos povos indígenas resultaram em revoltas cristãs e muçulmanas na cidade nigeriana de Jos, onde, entre 2001 e 2010, foram assassinadas mais de cinco mil pessoas. O presente estudo vem complementar a literatura disponível sobre a dimensão espacial da violência, centrando-se no modo como os bairros de Jos, outrora zonas residenciais, se transformaram em espaços de diferenciação étnica e de violência. Partindo de um estudo etnográfico, cartografa-se aqui e a emergência e o desenvolvimento de fronteiras e bastiões étnicos, dois tipos de enquadramento socioespacial que foram concebidos como ferramentas para ajudar a explicar a disseminação e os padrões de violência nos bairros de Jos.

Keywords: Ethnic violence; ethnoreligious conflicts; riots; neighborhoods; Jos; Nigeria; Africa

(Received 05 December 2017 - Revised 24 September 2018 - Accepted 25 September 2018)

\section{Introduction}

The city of Jos once ranked among Nigeria's most peaceful zones while ethnic conflict and religious extremism ravaged neighboring urban centers, including Bauchi, Kaduna, Gombe, and Kano, between the late 1960s and 1990s. Over the last fifteen years, however, Jos has gained notoriety as one of the country's most violent locations. Episodic Christian-Muslim clashes in the metropolis and the outlying settlements claimed over 5,000 lives between 2001 and 2010. ${ }^{1}$ Boko Haram bombings and revenge attacks followed, persisting until 2015. Experts have analyzed the structural factors that led to the Jos crises (Danfulani \& Fwatshak 2002; Egwu 2004; Best 2007; Higazi 2007; Ostien 2009), highlighting contestations over indigene rights, political representation, and city ownership. Beyond structural causations, Jos scholars have recently sought to explain the factors shaping the spatial distribution of violence in the different outbreaks (Krause 2011, 2017; Bunte \& Vinson 2016; Madueke 2018a, 2018b). This interest follows research trends for other violent cities including Belfast (Cunningham 2013; Mesev et al. 2009), Jerusalem (Bhavnani et al. 2014), Beirut (Bou Akar 2012), and Osh (Kutmanaliev 2015), while considerable work in this vein has been devoted to cities in India (Varshney 2001; Brass 2004; Wilkinson 2006; Berenschot 2011).

The case of Jos has contributed meaningfully to local and global discussions about the intersection between spatiality and collective violence. Jana Krause's (2017) paired comparison of violent and nonviolent neighborhoods in Jos demonstrated that civilian networks are a key determinant of neighborhood violence, more so than demographic and structural factors. She observed how the Dadin Kowa neighborhood remained non-violent thanks to the efforts of individuals and social networks who intervened to prevent youth from engaging in violence. While Krause emphasized civilian agency's role in violence prevention, Jonas B. Bunte and Laura Thaut 
Vinson (2016) illustrated how the presence or absence of power-sharing determined the level of violence or non-violence across Jos North and Chikun districts. In so doing, they presented a convincing account of how the politics of exclusion works to cause violence. Studies have long cited poverty as a structural factor underpinning ethnic violence in Africa (Elbadawi \& Sambanis 2000; Collier \& Sambanis 2005), but determining the way in which poverty and violence interact has been more elusive (Sambanis 2001). Explaining why the poorer neighborhoods of Jos are more susceptible to violence than their wealthier counterparts, Alexandra Scacco (2012) noted how residents of the former were forced to defend themselves and their families because the government did not provide adequate security for their areas.

On the basis of these strands of literature, we can see that initial studies on Jos offer key insights on the remote as well as the proximate factors that contributed to ethnic violence in a city once considered peaceful. These works draw attention to macro-level structural drivers of conflict such as scarcity, poverty, unemployment, inequalities, group competition, and historical antagonisms. More recent scholarly efforts, however, focus on the meso and micro levels, explaining how local processes within districts and neighborhoods can drive violence. Considered side by side, these studies advance our understanding of the drivers of ethnic conflict and violence on two different planes. Lacking is a sophisticated conceptualization of how factors at these two levels of analysis interacted to shape the violence in Jos. There remains much unearthing to do, especially in terms of micro-level dynamics. At a disaggregated level, we still seek to understand how neighborhoods which were once locales of peaceful coexistence and congeniality turned into arenas of atrocities. We also need a systematic examination of how different types of neighborhood settings shaped patterns of violence and how the violence reshaped them.

Taking up these tasks, this article selects the neighborhoods of Angwan Rogo and Nasarawa Gwong for its case study (see Figure 1). The analysis offers three major contributions to the field. First, in conceptualizing ethnic strongholds and frontiers, the article provides theoretical tools to make sense of the interaction between violence and its spatial context. Second, by examining what neighborhoods in Jos underwent, the study highlights transformational milestones that can be applied to understanding conflict in other cities struggling with similar security challenges. Third, profiling the two distinct settings and how they differentially contribute to violent outcomes produces practical tips for how authorities can respond to conflict with greater context sensitivity. Moreover, understanding what changes occurred in the two neighborhoods affords a general idea of what happened in other neighborhoods and helps explain why the violence spread rapidly across the city.

This article is part of a bigger project and builds on an earlier piece that foregrounded the historical dimension of the conflict. The previous publication brought to light how Jos's colonial antecedents contributed to setting in motion rivalries that have remained salient in present day politics of identity and contestations (Madueke 2018a). Advancing the discourse, the key objective of this article is to zoom in how the neighborhoods of the city 
Figure 1. Patterns of segregation in Jos city center (map created by author).

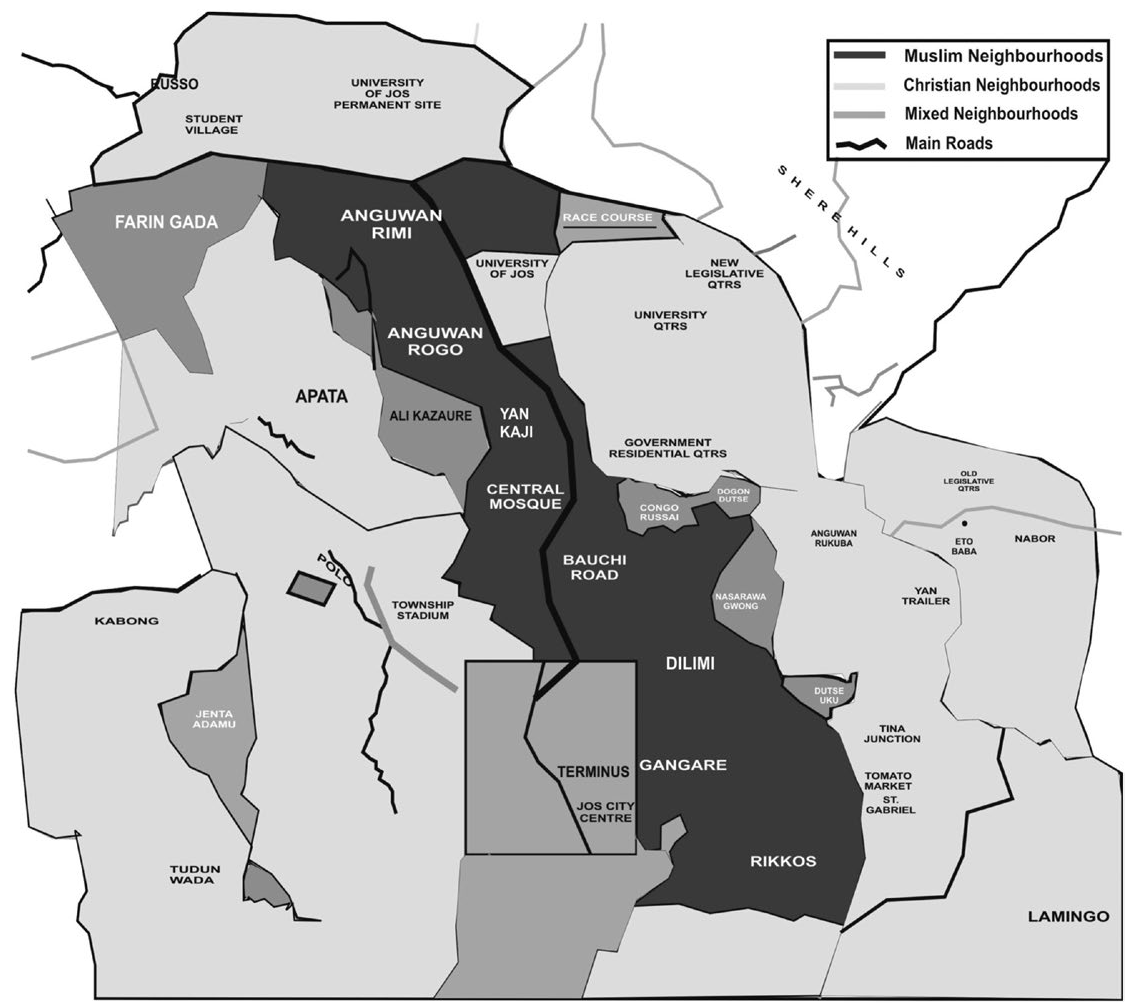

were transformed into militarized spaces. Another article in this series traced the footprints of rioters from where they mobilized into armed mobs to where they engaged in violence (Madueke 2018b). Together, these essays offer a comprehensive account of how history, spatiality, identity politics, and local group dynamics interwove and contributed to the transformation of a once-peaceful city into a site of deadly violence.

Though the concepts of strongholds and frontiers will be discussed in more detail subsequently, it is important to briefly describe their basic characteristics from the outset. At its barest form, the stronghold is a segregated settlement characterized by a high level of ethnic consciousness and group solidarity. The frontier, on the other hand, is an ethnically mixed setting that is sandwiched between rival segregated settlements and, as a result, is subject to territorial contestations. This article is primarily about the emergence and development of these socio-spatially distinct settings and how they differentially shaped and experienced violence. However, to provide context, it starts out with how and why Jos as an aggregate unit encountered ethnic violence in the first place. Divided into four sections, this article begins by chronicling factors underlying group relations and violent conflict in Jos and discussing political developments at the national, state, and municipal levels that shaped 
neighborhood-level group dynamics. The second section then describes the study's methods and data. The third traces how the aforementioned factors hastened Angwan Rogo's transformation into an ethnic stronghold and Nasarawa Gwong's into a frontier, and defines these two socio-spatial settings. The fourth section details the 2001 riots of Jos, noting how the stronghold and the frontier shaped patterns of violence and how the violence, in turn, completed the settings' transformations.

\section{The progression of ethnic conflict and the spatial dimension of violence}

Intergroup and intragroup dynamics at the neighborhood level were swayed by the same factors shaping the evolution of group relations in Jos. Relevant milestones include the politicization of ethnic identities in Nigeria during the 1980s, the creation of Jos North local government area (LGA) in 1991, the low-scale violence of 1994, the country's return to democratic government, the embargo on indigene certificates for the Hausa in 1999, and the violence of 2001. An outline of the events suffices for this article, though expert analyses exist (see Higazi 2011; Krause 2011; Ostien 2009; Best 2007; Egwu 2004).

Although politicization of ethnic identities in Nigeria has its origin in colonial rule, post-colonial events expedited the process. One definitive turning point was the 1986 implementation of the IMF and World Bank structural adjustment program (SAP), following a recession triggered by a fall in oil revenue. Intended to restructure consumption and production and to reduce dependence on crude oil and consumer goods imports, the SAP turned out to be counterproductive, plunging Nigeria into a major economic crisis (Anyanwu 1992:5). High unemployment followed due to cuts in government expenditure. Scholars have stressed the SAP's negative effects not only on the economy, but also on group relations (Ihonvbere \& Ekekwe 1988; Beckman 1991; Adetula 1992; Osaghae 1995; Nnoli 1998; Mustapha 2000; Egwu 2004). The overlap of SAPs and conflict proliferation elsewhere in Africa is well documented (Williams 2004; Sesay \& Ukeje 2009). In the wake of the SAP-precipitated austerity, Nigerians became discontent, and the military government's last flicker of legitimacy was extinguished (Jega 2000:36).

To relieve their plight, Nigerians looked beyond the state. A foremost source of succor was tribal and kinship ties (Egwu 2004:156). Growing ethnic consciousness coincided with rising ethnic associations (Osaghae 1995; Jega 2000; Egwu 2004). "Not only was there an upsurge in the membership of these associations," stated Eghosa Osaghae (1995:46), but also "there was a rapid expansion in their number, variety and purpose." The government was generally hostile to signs of dissent; trying to curry favor with citizens; it therefore deployed a system of patronage, seeking influential religious and tribal associations to redeem its legitimacy (Jega 2000:20). In 1987, during an "ethnicization of politics" or a "politicization of ethnicity" (Egwu 2004:32), the Jasawa Development Association (JDA) was born. Representing the 
Hausa population in Jos, this organization was a protagonist in the indigenesettler conflict that would ensue.

Meanwhile, several developments hastened the transformation of Jos's already politicizing residential areas into militarized ethnic strongholds and frontiers. The first was the creation of Jos North LGA. Nigeria has 774 administrative units known as LGAs. Jos North LGA is the economic capital of Plateau State and was carved out of the old Jos LGA in 1991 amid contestations between the indigenes and the Hausa. Experts have theorized how the new LGA intensified contestations over city ownership and added a territorial dimension to the issue (Best 2007; Ostien 2009; Higazi 2011; Krause 2011; Milligan 2013). In a climate of long-standing indigene resentment about the creation of Jos North, the city experienced its first wave of violent riots since the Igbo pogroms of 1966. Protests and counter-protests erupted after, in April 1994, Plateau State military governor Mohammed Mana appointed Aminu Mato, a Hausa, as chairman of the management committee of Jos North LGA. It is important to describe how the indigenesettler contestations find expression in the clamour for the creation of new states, LGAs, and districts. Following Nigeria's transition from military rule to democracy, the Middle Belt became a hotbed of identity politics as indigenous groups positioned themselves to take political control of what they believed were their territories against the overbearing presence of the Hausa-Fulani. These struggles are generally framed as indigene-settler conflicts, and nowhere in the country have they been as pronounced and atrocious as in Plateau State. A good part of the conflict manifests in the form of struggles for the creation of new states and LGAs by different groups. Apart from serving as the basis for gaining indigene status, these newly-created administrative units provide channels for accessing resources by groups that consider the status quo unfavorable. The creation of Jos North LGA out of the greater Jos metropolis signifies this dynamic and remains a crucial factor in ethnic conflict and violence in the city.

Other events helped spur the deterioration of relations. One was a return to democracy after military rule; the 1999 electoral campaigns were particularly acrimonious. More consequential, though, was the newlyelected chairman's embargo on indigene certificates for the Hausa community (Ostien 2009). Issued by LGA authorities to differentiate between indigenes and migrants or settlers, the certificate allows individuals to qualify for scholarships, school admissions, employment quotas, and tenured positions as heads of government ministries and agencies. The indigene certificate has been an infamous source of discrimination and conflict in Jos and elsewhere in Nigeria (Abdullahi \& Saka 2007; Sayne 2012; Fourchard 2015; Ehrhardt 2017). It has been noted that in refusing to grant indigene certificates to members of the Hausa community, the Chairman of Jos North LGA had the backing of the governor at the time, Joshua Chibi Dariye. This, it is suggested, is indicative of the partisan stance of the governor and other top government officials in the conflict. Apart from this, the state government has been accused of indifference and incompetence in 
responding to key issues and developments in the build-up to the outbreak of violence (Ostien 2009). Denying the Hausa indigene certificates directly contributed to the fracas culminating in large-scale violence two years later, though, as it will be shown, the last straw was the July 2001 appointment of a Hausa to serve as coordinator for a federal government poverty alleviation scheme for Jos North. His appointment resulted in acrimonious exchanges between indigenes and Hausa, and that September, riots erupted.

\section{Research Methods and Data}

This study is based on fieldwork conducted in Jos between 2015 and 2017. Because, as Paul Brass (2004:4839) stated, "quantitative, statistical analyses cannot demonstrate the existence of a dynamic process," I pursued an ethnographic approach that could capture processes at a disaggregated level. Data sources include interviews, primary school common entrance registers, and election results, alongside informal discussions conducted in neighborhoods, motor parks, and other public places. This ethnography marks the first time primary school registers were used to systematically approximate the ethnic composition of Jos neighborhoods and how it changed during the study period.

\section{Interviews and Discussions}

The research draws from forty-seven interviews. Respondents included local politicians, neighborhood leaders, representatives of ethnic associations (tribal and religious), youth leaders, taxi and bus drivers, eyewitnesses, survivors of violence, and residents of the two neighborhoods as well as of the adjoining areas; eighteen interviews took place in Angwan Rogo, fifteen in Nasarawa Gwong, and fourteen in adjacent settlements. I sampled informants through an innovative search system that combined elements of snowballing and purposeful sampling. Since my primary goal was to examine the trajectory of transformation that goes back about a decade, length of residence and keen understanding of the dynamics of associational life, politics, and violence in the neighborhoods were crucial considerations in the sampling process. All the people interviewed experienced the violence of 2001 firsthand, and many were either perpetrators or victims of violence.

The interviews focused on the various aforementioned events that took place between the 1990s and the early 2000s. Thematic analysis was used to distill interviews and archival material. For each event, responses to the four questions were coded into four categories. The first category sought to capture how negatively or positively each group experienced the event. The second noted positive or negative effects on intergroup relations, including whether the event had a polarizing effect or some other influence and any impact on intragroup dynamics (e.g., if groups become more cohesive). The third category detailed the event's implications for 
the dynamics, form, operations, and activities of social networks; also considered were implications for social groups such as residents' associations, vigilantes, and campaign teams. Finally, the fourth category documented the event's effects on ethnic composition, particularly whether segregation levels in a neighborhood rose. For the discussion concerning 2001, violence patterns and levels in the neighborhood were noted (e.g., if violence took the form of pogroms, clashes, or sporadic isolated incidents). After organizing interview responses into coherent themes based on the negative or positive effect an event had on group relations, I ordered them chronologically and re-contextualized them into a coherent story. The interviews were analyzed in a manner that directly addresses this article's central concern: to empirically demonstrate the changes neighborhoods underwent in the lead-up to large-scale violence. This approach seeks to reveal each event's effect on intragroup and intergroup dynamics. Moreover, it aims to understand how group relations degenerated to the point that residents who co-existed peacefully for many years rationalized picking up arms and attacking each other.

\section{Primary School Common Entrance Registers}

Because the Nigerian census does not include ethnic categories, I used public primary school composition as a proxy for the ethnic composition of the neighborhood in which the school is located. I took the graduating class as a representative sample of the school, since these pupils all sit for the common entrance examination. I analyzed registers for the classes of 1990, 1995, 2000, and 2005, seeking any remarkable patterns in the buildup to the 2001 violence and afterwards. I began by categorizing the pupils as "Muslim" or "Christian"; in Jos and much of Nigeria, names often reflect individuals' religions. However, because this does not apply in all cases, I conducted "ground truthing" discussions with school principals and teachers to further ascertain Christian-Muslim proportions.

\section{Election Results}

The 2015 general elections provided a general idea of variations in voting patterns in ethnic strongholds and frontiers. I used the 2015 presidential election since records for elections in 1999 and 2008 were either inaccessible or unavailable; LGA elections, moreover, were not held in Jos North between 1999 and 2008.

The datasets had inevitable biases and limitations. An ethnic group might have been overrepresented or underrepresented in a school or a class by chance or for various other reasons. In interviews, respondents might have twisted events to suit their own narratives, and memories of some occurrences from several decades back might have been fuzzy. Also, as mentioned, most elections results proved inaccessible. To address these concerns, I conducted a robust "ground truthing" process that involved 
visits to the neighborhoods, close observation, and discussions with a crosssection of residents. Additionally, I assessed the veracity of seemingly outrageous claims by triangulating different sources of data.

\section{The Evolution of an Ethnic Stronghold}

To explain an ordinary residential area's transformation into an ethnic stronghold, I begin with a description of this type of socio-spatial setting. At its basic level, a stronghold is a segregated settlement where one ethnic group predominates and controls the prevailing way of life. A Muslim stronghold, for example, has a visible presence of mosques, Koranic schools, and other Islamic institutions, while Christian institutions are few or nonexistent. The ethnic stronghold may be surrounded by areas of similar ethnic composition, though at least part of its boundary is shared with an ethnically mixed area, which, in turn, shares a boundary with a stronghold that rivals the ethnic stronghold. The ethnic segregation in the stronghold masks other peculiarities, such as a high level of ethnic solidarity that becomes manifested in collective behavior such as voting for the same political party or candidate (Olzak 1983:357).

The stronghold helps conceptualize how identities are constructed and reconstructed (Nagel 1994) within a spatialized emergent subculture. Susan Olzak (1983:356) explains the type of solidarity in the stronghold as "the conscious identification with a given ethnic population" that "includes the maintenance of strong ethnic interaction networks and institutions that socialize new members and reinforce social ties." Mobilizing co-ethnics for collective violence is more feasible in a stronghold setting (Fearon 2006), which breeds opportunity for cost-free intragroup communication (Weidmann 2009). Mobilizing residents into mobs is easier in the safety of segregated areas where "contentious claim making gains protection from routine surveillance and repression because of terrain, built environment" (Tilly 2000:144).

But segregation and solidarity are not the only elements. A stronghold is characterized by the presence of politicized and militarized social networks comprising local politicians, self-proclaimed ethnic activists, gangs, thugs, and ordinary residents. These actors play complementary roles which are crucial for accomplishing collective goals, though they are also driven as individuals with personal objectives, such as securing money, jobs, and favors. Within the networks are social subsystems analogous to riots systems (Brass 2004) and patronage networks (Berenschot 2011) that fuel and sustain violence. They are characterized by "complex webs of exchange, obligation, and reciprocity... sustained over a long period of time" (Kitschelt \& Wilkinson 2007:19). For local criminals, gaining the patronage of local politicians may motivate riots, though the chaos also provides opportunities to loot and get away with crime. Looting has long been recognized as a key activity in the dynamics of ethnic riots (Mac Ginty 2004; Dynes \& Quarantelli 1968). 
These characteristics apply to the Muslim stronghold of Angwan Rogo, a poor neighborhood north of Jos's city center. After the 2001 violence, the population of the settlement became homogenously Muslim (see table 1), with over 100 mosques and Koranic schools (a figure counting the many garages and verandas used for praying and teaching); the only two churches that once stood were both destroyed in the violence.

Angwan Rogo's demographics mean that its civic structures and all social networks, both formal and informal, are comprised entirely of co-ethnics. Residents' associations and vigilante groups are intra-ethnicnot a single network member is non-Muslim. ${ }^{2}$ Consequently, voting patterns reflect strong ethnic allegiance (see table 2). Political "black sheep" are discriminated against or harassed, as illustrated in the 2015 elections, when arsonists set fire to the house of PDP chieftain Adams Alkali, a resident of the APC-dominated Angwan Rogo. ${ }^{3}$ The arsonists were part of the violent network that helped the neighborhood maintain itself as a stronghold.

Violent networks present more than a security challenge for the neighborhoods in which they are embedded. They also pose a major threat to adjoining neighborhoods, especially when those neighborhoods are ethnically mixed. During all major episodes of violence in Jos, armed mobs from Angwan Rogo marched into the nearby ethnically mixed area to fight against Christian groups from there and from the adjoining Christian strongholds. Because of this and despite no major incidents of violence within Angwan Rogo since 2001-there are simply no Christians to fight within the neighborhood-the neighborhood is still a notorious trouble spot. Along with a few other neighborhoods in the city center, it is an area frequently featured in media and official reports of riots in the city.

But Angwan Rogo was not always an ethnic stronghold. Although Muslims seem to have long dominated the settlement, Christians comprised up to 34 percent of the population in 1995 and 25 percent before the 2001 violence, as indicated in table 3 . Regardless of its precise ethnic composition, Christians and Muslims once peacefully coexisted, as many residents affirmed. An elderly former resident, now living in Furaka, contrasted the congeniality of the 1970 s and 1980 s with the present-day discord:

I remember how we used to celebrate Christmas there. Muslims would come to our house and eat whatever we had to offer. During their Salah [Muslim festivity], we would visit them and also eat with them... That is how it was, but something really went wrong and here we are. Today the situation is very different. I can't feel safe there and they can't feel safe here. ${ }^{4}$

So what changed? Between 1990 and 2000, Angwan Rogo's ethnic composition transformed. The percentage of Muslims grew from 64 to 75, while that of Christians dropped from 33 to 25. Everyday migrations may account for some changes, though three major events could well have spurred the demographic shift. 
Table 1. Ethnic composition of Angwan Rogo, 2000-2005

\begin{tabular}{llclll}
\hline Year & $\begin{array}{l}\text { Number of } \\
\text { pupils }\end{array}$ & $\begin{array}{l}\text { Number of } \\
\text { Christians }\end{array}$ & $\begin{array}{l}\text { Percentage of } \\
\text { Christians }\end{array}$ & $\begin{array}{l}\text { Number of } \\
\text { Muslims }\end{array}$ & $\begin{array}{l}\text { Percentage of } \\
\text { Muslims }\end{array}$ \\
\hline 1990 & 281 & 94 & 33 & 187 & 67 \\
1995 & 363 & 125 & 34 & 238 & 66 \\
2000 & 219 & 54 & 25 & 165 & 75 \\
2005 & 186 & 0 & 0 & 186 & 100 \\
\hline
\end{tabular}

First, Jos experienced waves of in-migration as people fled the firestorm of violence engulfing parts of northern Nigeria in the 1980s and 1990s. Riots sparked by the Maitatsine fundamentalist group led to thousands of deaths and many more displacements in Kano, Adamawa, Gombe, and elsewhere. Christian-Muslim clashes in Kaduna in the late 1980s devastated communities and displaced thousands, some of whom sought refuge in the slum areas of Jos such as Angwan Rogo (Nyam \& Ayuba 2016). It is also possible that-as personal discussions and one source suggest-some Maitatsine extremists settled in Angwan Rogo during military actions against them in northern Nigeria. ${ }^{5}$ These fugitives could have propagated their ideology of violent extremism among some residents of the neighborhood.

Second, once Jos North was created in 1991, the Hausa felt the new LGA belonged to them. Its emergence was mainly the result of lobbying by the JDA on behalf of the Hausa community. Once it was created, many Hausa who had no indigene status where they lived relocated to the new LGA, imagining they could easily gain status there. Many came from other parts of the metropolis, such as Bukuru; others came all the way from Bauchi. ${ }^{6}$ Once in Jos, these newcomers found Angwan Rogo a convenient place to settle down because of pre-existing social ties and cultural and linguistic affinity. ${ }^{7}$ Another event that affected the demography of Angwan Rogo was the low-level violence in parts of Jos in 1994. Four Muslim individuals were killed in these riots. The fact that all four killed were Muslims was a source of major grievance. ${ }^{8}$ Of the 104 people arrested in connection with the violence, twenty-one were Christian and eighty-three were Muslim.

Table 2. Ethnic composition and voting patterns in Angwan Rogo and the nearby settlement of Ali Kazaure

\begin{tabular}{|c|c|c|c|c|c|c|c|}
\hline $\begin{array}{l}\text { Neighborhood/ } \\
\text { polling unit }\end{array}$ & $\begin{array}{l}\text { Predominant } \\
\text { group }\end{array}$ & $\begin{array}{l}\text { Number } \\
\text { of votes }\end{array}$ & $\begin{array}{l}\text { Number } \\
\text { of APC } \\
\text { votes }\end{array}$ & $\begin{array}{l}\text { Percentage } \\
\text { of APC } \\
\text { votes }\end{array}$ & $\begin{array}{l}\text { Number } \\
\text { of PDP } \\
\text { votes }\end{array}$ & $\begin{array}{l}\text { Percentage } \\
\text { of PDP } \\
\text { votes }\end{array}$ & $\begin{array}{l}\text { Percentage } \\
\text { of other } \\
\text { party votes }\end{array}$ \\
\hline Angwan Rogo I & Muslim & 756 & 755 & 99.8 & 1 & 0.2 & 0 \\
\hline Angwan Rogo II & Muslim & 688 & 683 & 99.3 & 2 & 0.3 & 0.4 \\
\hline Ali Kazaure I & Mixed & 641 & 341 & 53.2 & 300 & 46.8 & 0 \\
\hline Ali Kazaure II & Mixed & 222 & 173 & 78 & 49 & 22 & 0 \\
\hline
\end{tabular}


Table 3. Ethnic composition of Nasarawa Gwong, 1990-2000

\begin{tabular}{llllll}
\hline Year & $\begin{array}{l}\text { Number of } \\
\text { pupils }\end{array}$ & $\begin{array}{l}\text { Number of } \\
\text { Christians }\end{array}$ & $\begin{array}{l}\text { Percentage of } \\
\text { Christians }\end{array}$ & $\begin{array}{l}\text { Number of } \\
\text { Muslims }\end{array}$ & $\begin{array}{l}\text { Percentage of } \\
\text { Muslims }\end{array}$ \\
\hline 1990 & 170 & 99 & 58 & 71 & 42 \\
1995 & 156 & 77 & 49 & 79 & 51 \\
2000 & 159 & 67 & 42 & 92 & 58 \\
\hline
\end{tabular}

The disparity in the number of arrests was also a source of frustration for many Muslims. ${ }^{9}$ A former Gada Biyu resident told me that a number of Muslims relocated from the area to seek safety in neighborhoods such as Angwan Rogo, where their co-ethnics were in the majority. ${ }^{10}$

Alongside the shifting Christian-Muslim ratios, social network dynamics were being shaken up. The ethnicization of neighborhood-based social networks in Angwan Rogo provides a salient example. Before the new LGA, the residents' association had no concrete religious or ethnic links. After its creation, however, the JDA found new prestige among residents of Angwan Rogo because it fulfilled Hausa wishes for Jos North. As a local politician noted of the JDA, "its role in the creation of the new LGA made the people have confidence in it." 11 The organization thus earned greater credibility and control over neighborhood-based civic structures in areas with a Hausa majority. In Angwan Rogo, prominent JDA members took lead roles in the residents' association and, in turn, neighborhood association leaders became more involved in the JDA. ${ }^{12}$ This marked an important stage in the ethnicization of the residents' association and, in time, vigilante groups. Furthermore, it all fit within the broader politicization of ethnic identities and associations, catalyzed by the SAP along with other factors at the national level.

Although the 1994 violence was low-level and Angwan Rogo remained nonviolent, it marked a crucial formative stage in the neighborhood's militarization. It was the first time that some residents organized themselves into aggressive mobs on the basis of ethnic identity within Angwan Rogo. Brass (2004) noted how, in the Indian city of Meerut, violent riots in 1961 brought about the development of "riot systems," - violent networks enabling large-scale violence-decades later, in 1982. In Jos, the 1994 violence similarly laid the groundwork for the horrendous acts of 2001. Several informants, including former residents, recalled that although Angwan Rogo was technically violencefree during the fighting, tension was palpable and almost led to physical confrontations in some instances when dozens of young men mobbed around and threatened Christians. A former resident looked back on 1994's implications for future group relations in the neighborhood:

It was simply because of God's grace that there was no fighting in the area. The young people were moving around in groups angrily as if ready to attack. Fortunately, some older residents called some of the young men and cautioned them against engaging in violence... violence did not 
happen, but I can tell you some of us knew that it was only a matter of time. You can say that was the time that an army for future fighting really started building up. ${ }^{13}$

Nigeria's return to a democratic system in 1999 heralded another phase in the evolution of Angwan Rogo. Research on the Banyamulenge of South Kivu in the DRC has demonstrated how clamor for political participation in Africa's new democracies not only ossifies ethnic boundaries, but also facilitates "the shift to massive violence as an enticing strategy of control and resistance" (Vlassenroot 2002:499). Campaign rhetoric in Jos was strongly framed in ethnic terms. The PDP ran with the narrative that the ANPP was a political instrument for the takeover and Islamization of Jos by the Muslim Hausa. Christians bought into it, and soon churches provided platforms to campaign against an imminent "Islamic takeover" and for support of PDP candidates at various levels. In turn, ANPP stalwarts in Jos embraced a narrative of victimhood, saying that Muslims (and not just the Hausa) in Jos had been marginalized by Christians, who had monopolized positions of power and distributable resources. ${ }^{14}$ The reversal of Mato's appointment and the resultant riots in which all four people killed were Muslims were commonly cited as evidence to support the narrative. Muslim clerics championed the narrative and, analogous to what the churches were for the PDP, mosques were for the ANPP. ${ }^{15}$ Krause (2011:30) observed that "both politicians and religious leaders" urged "their followers to vote along religious lines." A respected religious leader, speaking before the 2015 elections, echoed the mood of Angwan Rogo back in 1999:

By the grace of Allah, Jos North cannot be rigged. Come to think of it, was there an election somewhere that was won and not announced? When it became apparent that we had won and they had to announce, did they not cancel the elections? For your information, this upcoming election cannot be cancelled and by force we shall win, Allah willing. Look, we are Muslims, over eighty percent of the people of Jos North are Muslims. We are not Christians. Do you think we shall vote a Christian to lead us in Jos North? ${ }^{16}$

Expressing solidarity with their co-ethnics around the city, Angwan Rogo residents did not leave onlookers to doubt which political party they supported. Several neighborhood-level party offices were located there, and they, along with many other buildings, were painted in ANPP official colors and flaunted the party logo. Almost four years after the ANPP merged with two other parties to form the APC, its green, white, and blue still showed on some walls in Angwan Rogo. But more than the aggressive campaigns that preceded the 1999 elections, an embargo on issuing indigene certificates to Hausa is what worsened Christian-Muslim relations and further polarized social networks in Angwan Rogo. ${ }^{17}$ Discussions suggest this development was particularly hurtful to the Muslim residents. ${ }^{18}$ Having lost the elections and being denied indigene certificates, the Hausa turned 
to what they had left-their neighborhoods-and feared these too could be taken away. ${ }^{19}$ Further exacerbating these fears, rumors that the Plateau State government was planning to relocate residents of Angwan Rogo started gaining traction. 20

\section{The Making of the Frontier}

As popularized by Joël Kotek (1999:228), the notion of the frontier was identified as something that is foremost located on fault lines between ethnic, religious, or ideological wholes. Second, it is a disputed area characterized by contestations and struggles for political control between rival groups. Third, it symbolizes greater conflicts, being "emblematic of larger disputed areas or zones" (Kotek 1999:231). Struggle for control in the frontier is thus not restricted to residents within the socio-spatial setting, but also involves actors from adjoining areas. For this study, I define the frontier as an ethnically mixed neighborhood between two rival segregated neighborhoods. Determining the dominant group is difficult, on paper at least, because the two ethnic identities are proportionally represented. The frontiers of Jos have a presence of both Christian and Muslim institutions. The frontier is analogous to a contested boundary wherein the presence of the rival group is perceived as a threat (Legewie \& Schaeffer 2016). This resonates with Neil Jarman and Chris O'Halloran's (2001) "buffer interface," used to argue that in Belfast's contested landscape, ethnically mixed areas located between segregated settlements experience more violence than homogenous neighborhoods divided by sharp boundaries.

The frontier of Nasarawa Gwong has three elemental characteristics. It is ethnically mixed (see table 3). Christian and Muslim residents are represented by parallel civic structures and social networks. And it is located between two segregated settlements, each dominated by one of the rival groups. To the north is Angwan Rukuba, a Christian neighborhood, and to the south are the contiguous Muslim settlements of Dilimi and Gangare.

Apart from rivalry within, Nasarawa Gwong is characterized by struggles between rivals from adjoining strongholds seeking to dominate Nasarawa Gwong. Ordinarily, mixed areas are plagued by internal conflicts, while the frontier suffers from struggles between rivals inside and outside its territory. In all major episodes of violence experienced in Jos, armed mobs from the Christian strongholds of Angwan Rukuba and Tina Junction marched into Nasarawa Gwong against advancing fighters from the Muslim strongholds of Dilimi and Gangare, along with their co-ethnics in Fillin ball and Yan Shanu areas. Comparatively, more incidents of violence have occurred here than elsewhere in the city, and it is recognized as one of the most notorious battlegrounds (Human Rights Watch 2009:9).

But Nasarawa Gwong was also once a bastion of peaceful co-existence. Christian and Muslim residents belonged to the same neighborhood-based networks. Although ethnic identity determined social ties to some extent, 
the general sense of neighborliness and friendship transcended ethnic boundaries. As one elderly resident recalled: "It was not uncommon to find Christians and Muslims exchanging visits and, during elections, Christians voting for a Muslim candidate or Muslims voting for a Christian."21

So what went wrong? The same events and political developments that made Angwan Rogo a stronghold made Nasarawa Gwong a frontier. Jos North's 1991 creation was one of the foremost causes of dissonance between Christian and Muslim residents in the area. Ethnic antipathy that befell the city was acute in Nasarawa Gwong and, according to one resident, polarized the neighborhood's residents' association:

\begin{abstract}
At a point everyone knew we had to part ways. Muslims had their agenda and Christians had theirs. There was no way we could work together because there was no trust. The Muslims were celebrating the creation of the new LGA and Christians were very sad about the development. We just parted ways. Christian residents started having their meetings and Muslims also started having their meetings. But it was different before then, we used to have our meetings together... but that was before the creation of Jos North. ${ }^{22}$
\end{abstract}

Besides going separate ways, social networks started aligning with their co-ethnics in the adjoining segregated settlements:

It was a situation where the Muslim in Nasarawa Gwong was closer to his Muslim brothers in Yan Shanu, Dilimi and Gangare than his Christian neighbors. The Christian in Nasarawa Gwong abandoned his Muslim neighbors and associated more with his Christian brothers in Angwan Rukuba and Tina Junction. Even the associations did the same thing. So you find vigilantes from here working with their brothers in the nearby settlements; no one wants to work with their neighbor who is of a different religion. ${ }^{23}$

Appointment of a Muslim as management committee chairman for Jos North, the 1994 riots, and acrimonious 1999 election campaigns all exacerbated the already worsening group relations between the Hausa and the indigenes in Nasarawa Gwong. The 1994 violence marked a crucial stage in the neighborhood's polarization and militarization. Co-ethnics banded together to form small armed groups and did a lot of surveillance work around their homes. ${ }^{24}$ Future events would illustrate just how the 1994 riots let groups in Nasarawa Gwong rehearse what would come seven years later.

During the 1999 election campaigns, Nasarawa Gwong was divided into two main political camps. Christians aligned with the PDP and Muslims with the ANPP. ${ }^{25}$ During the elections, youth networks were coopted to become campaign organizations. ANPP youth wings comprising Hausa young men staged campaign rallies and road shows in Fillin Ball, Yan Shanu, and elsewhere in the neighborhood. The politicking involved display and dissemination of political posters as well as directly engaging with residents. One former youth wing member who doubled as a vigilante described how he and his peers became part of ANPP's campaign machinery. 
The older and more established members of the party know that they need the youth to succeed. That is why they approached us as a group to enlist our support. But before working with them we gave them conditions. For example, we told them that we wanted employment, school admissions, and small loans to start businesses. These are some of the things that the youth needs and that is why we joined ANPP, because we saw that the party members were the kind of people that would provide us with these things. ${ }^{26}$

Indigene youth networks in Nasarawa Gwong also had major roles in organizing campaign activities for the PDP. One local politician said it was at the height of the 1999 elections that he and many Christian peers joined the youth wing:

PDP was new then and they were looking for members. It was one elder in this area who approached me. I immediately agreed to join because he was a man I respected. I told some of my friends about it and they also joined. That was how we joined the campaigns. We started in this neighborhood, traveled to other towns, and still brought back the campaigns to this neighborhood because ANPP was also strong here, very strong. ${ }^{27}$

Transboundary alliances existed between ethno-political networks in Nasarawa Gwong and its adjoining areas. PDP loyalists in Nasarawa Gwong organized joint campaigns with their counterparts from the adjacent Christian stronghold of Angwan Rukuba. ANPP supporters in Nasarawa Gwong collaborated with their co-loyalists in the Muslim strongholds of Yan Shanu, Dilimi, and faraway Gangare. ${ }^{28}$ This cross-border politicking led to skirmishes best described as turf wars between youth wings of the rival political parties at different stages of the campaigns. ${ }^{29}$ Although I could not access any 1999 voting records for Nasarawa Gwong, my discussions with local politicians and eyewitnesses painted a picture of what happened. Ostensibly, the neighborhood proved to be a frontier where rival ethno-political networks from the adjoining areas competed to gain control of the polling units. Political activists and thugs working with local politicians from the Christian stronghold of Angwan Rubuka invaded and took control of those polling units nearest to them, notably those around Chwel-Nyap public primary school. Similar networks from the Muslim strongholds of Yan Shanu and Fillin Ball invaded and took control of the polling units around them. Table 4 shows voting patterns in some segregated and mixed areas of Nasarawa Gwong. ${ }^{30}$

Although this data is based on 2015 elections, I was told by local politicians and other individuals that prior voting patterns were similar. The ethnic identity of the candidates was the biggest consideration for most voters. Polling units Ungwar UNA I and II formed the highly contested middle ground where each group struggled to extend the frontier of their political dominance. One eyewitness said that during the 1999 elections, he saw at least two fistfights and several heated verbal confrontations involving political thugs from neighboring areas. Is it surprising that this area provided the arena for some of the fiercest clashes barely two years later? 
Table 4. Ethnic composition and voting patterns in ethnically mixed and segregated polling units of Nasarawa Gwong

\begin{tabular}{|c|c|c|c|c|c|c|c|}
\hline $\begin{array}{l}\text { Neighborhood/ } \\
\text { polling unit }\end{array}$ & $\begin{array}{l}\text { Predominant } \\
\text { group }\end{array}$ & $\begin{array}{l}\text { Number } \\
\text { of votes }\end{array}$ & $\begin{array}{l}\text { Number } \\
\text { of APC } \\
\text { votes }\end{array}$ & $\begin{array}{l}\text { Percentage } \\
\text { of APG } \\
\text { votes }\end{array}$ & $\begin{array}{l}\text { Number } \\
\text { of PDP } \\
\text { votes }\end{array}$ & & $\begin{array}{l}\text { Percentage } \\
\text { of other } \\
\text { party votes }\end{array}$ \\
\hline Ungwar UNA I & Mixed & 257 & 77 & 30 & 150 & 58 & 12 \\
\hline Ungwar UNA II & Mixed & 372 & 103 & 28 & 261 & 70 & 2 \\
\hline Yan Shanu I & Muslim & 393 & 391 & 99 & 1 & 0.5 & 0.5 \\
\hline Yan Shanu II & Muslim & 596 & 591 & 99 & 4 & 1 & 0 \\
\hline
\end{tabular}

\section{Patterns of Violence in the Stronghold and the Frontier}

Barely two years after the indigene certificate embargo, another incident animated the acrimony surrounding the question of indigeneity. In July 2001, the federal government of Olusegun Obasanjo appointed LGA coordinators for the National Poverty Eradication Program (NAPEP). Mukhtar Usman Mohammed, a Muslim Hausa, was appointed to head the agency's Jos North branch. The indigenes rejected the appointment, maintaining that Mohammed was not an indigene and did not qualify for the position; the Hausa insisted it must stand. Bitter correspondence, posters, and handbills were the vehicles used to swap threats in the following months. In different neighborhoods, countless posters were slapped on walls or dropped in public places, bearing messages of hate, with each group claiming to be the more powerful. ${ }^{31}$ Nasarawa Gwong was a hotspot for the printed matter, with several residents recounting how posters and handbills were flying about in the weeks before violence erupted. ${ }^{32}$ One resident said about five posters were put up on the wall of his house. ${ }^{33}$

After an interlude of uneasy calm-during which inflammatory exchanges still continued-the storm hit. Ethnic violence erupted in Jos on September 7, 2001. The triggering incident is well documented in academic and official reports (see Human Rights Watch 2001; Best 2007; Ostien 2009; Higazi 2011; Krause 2011), though a recap here suffices. That day, a young Christian named Rhoda Haruna Nyam was on her way to lunch and insisted on passing a group of Muslims who had blocked the road as they usually did during Friday prayers. An altercation ensued following an attempt to prevent the woman from accessing the route. Accounts differ on what happened from this point onward, but one account, consistent with what one resident of the neighborhood told me, is that she ran back to the Christian-dominated part of the neighborhood and shouted for help. ${ }^{34}$ Shortly afterward, Christian and Muslim residents of the neighborhood engaged in a series of attacks and counterattacks that, with surprising swiftness, spread throughout the city. Once the violence was underway, it was clearly no longer indigenes versus Hausa, but rather Christians and Muslims attacking each other. ${ }^{35}$

Researchers and NGOs have documented the violent events that transpired from September 7 to 12, 2001, and in some instances, highlighted 
their spatial patterns (see Human Rights Watch 2001; Best 2007; Higazi 2007; Ostien 2009; Krause 2011; International Crisis Group 2012). Adam Higazi (2007:17) described the mass killing of Christians in the Muslim-dominated areas of Angwan Rogo, Angwan Rimi, Bauchi Road, Sarkin Mangu, and parts of Nasarawa Gwong, as well as the mass killing of Muslims in the Christiandominated areas of Angwan Rukuba, Jenta Adamu, Bukuru Road, and Zaria Road. Krause (2011) noted similar patterns of violence, how Angwan Rogo became "exclusively Muslim" after the attack on the Christians there, and how Christians attacked and drove Muslims out of Apata. Further, she observed how the ethnically mixed area of Ali Kazaure "became a battleground between both groups" (Krause 2011:36).

These accounts in the literature and in my research help illustrate how patterns of violence varied between ethnically segregated and mixed neighborhoods. Drawing from established understandings of "patterns" of violence (Tilly 2003; Kalyvas 2006, 2012; Gutiérrez-Sanín \& Wood 2014, 2017), I adopt an interpretation that distinguishes between two types of "patterns": pogroms in the form of asymmetric attacks by the majority on a defenseless minority; and clashes in the form of symmetric combat between groups. Patterns of violence can be categorized into far more forms, but these categories here suffice.

In segregated areas and neighborhoods that were clearly dominated by one rival group, members of the dominant group attacked the minority in a series of pogroms. Fighting was principally asymmetric, with the minority mainly on the defensive. As the literature documents, in Angwan Rogo, large mobs of Muslims attacked Christians. Armed with sticks, knives, machetes, bows and arrows, guns, and petrol bombs, the irate crowds moved from one Christian home to another, killing, maiming, and burning. They spared women and children only in some instances. The Christians, who were heavily outnumbered, did not fight back. Two churches, homes belonging to Christians, and other properties were destroyed. Casualties included many University of Jos staff and students residing in the area because it was close to campus (Human Rights Watch 2001).

Violence assumed a different pattern in ethnically mixed Nasarawa Gwong. One neighborhood resident described it as "a war where groups stood at a distance and shot at each other and occasionally engaged in close combat." 36 This is consistent with Krause's depiction of the violence unfolding "along improvised front lines" (cited in Human Rights Watch 2001:9). Different parts of Nasarawa Gwong including Duala, Bulbula, and Angwan Keke were battlegrounds where Muslim and Christian mobs from the adjoining areas clashed repeatedly. 37 These clashes resulted in hundreds of killings and injuries and massive destruction on both sides.

After six days of fighting, the military restored order. It is estimated that at least 1,000 people were killed (Human Rights Watch 2001:9), though some sources claim it may have been 3,000 (see Danfulani \& Fwatshak 2002). Angwan Rogo alone saw hundreds murdered and the destruction of dozens of houses. In Nasarawa Gwong and surroundings, over a hundred people 
Table 5. Ethnic composition of Nasarawa Gwong, 2000-2005

\begin{tabular}{llllll}
\hline Year & $\begin{array}{l}\text { Number of } \\
\text { pupils }\end{array}$ & $\begin{array}{l}\text { Number of } \\
\text { Christians }\end{array}$ & $\begin{array}{l}\text { Percentage of } \\
\text { Christians }\end{array}$ & $\begin{array}{l}\text { Number of } \\
\text { Muslims }\end{array}$ & $\begin{array}{l}\text { Percentage of } \\
\text { Muslims }\end{array}$ \\
\hline 2000 & 159 & 67 & 42 & 92 & 58 \\
2005 & 160 & 62 & 39 & 98 & 61 \\
\hline
\end{tabular}

were reportedly killed and countless homes, businesses, vehicles, and other properties demolished. The most obvious aftereffect of the violence in the stronghold was increased segregation. Survivors fled to temporary camps for displaced persons that dotted the city in the following months; later they found shelter in co-ethnic-dominated areas. The Muslim neighborhood of Angwan Rogo hence became homogenous, as did the Christian neighborhood of Apata (Krause 2011:36). The ethnic composition of the residents' association, the vigilante groups, and other neighborhood-based organizations thus also became homogenous, further blurring the boundary between civic structures and ethnic associations. The frontier neighborhood of Nasarawa Gwong also experienced displacements and relocations, with Christian and Muslim residents each receding into the adjoining strongholds. Many Christians relocated from the neighborhood's north to seek refuge in the Christian strongholds of Angwan Rukuba and Tina Junction or even farther towards Furaka. Some Muslims around Angwan Rukuba junction and Dutse Uku also relocated south, towards Fillin Ball, Yan Shanu, and deeper into the Dilimi and Gangare areas. The proportion of Christians to Muslims decreased, but not significantly, as table 5 shows.

Insecurity and fear are known to precipitate segregation (Rodgers 2004:113). Members of both groups, especially those living in more ethnically diverse areas, showed some unwillingness to leave. Even some who fled these areas later returned. As a result, some parts of the city remained ethnically mixed, and these were the main battlegrounds for the violence of 2008 and 2010.

\section{Conclusion}

Scholars have devoted considerable attention to the SAP's devastating ramifications for Nigeria, creation of Jos North LGA, the country's return to a democratic government, and an embargo on issuing indigene certificates to the Hausa in Jos. This article, however, has focused explicitly on how these events transformed the neighborhoods in Jos from mundane residential areas into spaces of ethnic differentiation and violence. It has provided a fine-grained analysis of the dynamics of violence within and across neighborhood boundaries. This article thus builds on existing literature and adds value to the practice of responding to ethnic violence in several important ways.

To start with, in ordering neighborhoods into ethnic strongholds and frontiers and tracing the processes that underpin their emergence and 
development, the article elucidated a useful conceptual framework for coherently investigating, understanding, and explaining variations in the spread and patterns of violence in a divided city. Rather than conceiving of violence as completely chaotic, haphazard, and decontextualized from its socio-spatial context, the concepts uncovered how patterns of violence recursively interrelate with the demographic and physical environment in which they occur. Thus, as demonstrated, ethnic strongholds and frontiers are both a consequent and a predicator of particular violent forms.

Moreover, the cross-sectional approach of most studies on spatial patterns of violence offers a snapshot, failing to capture the dynamic socio-spatial conditions that support and shape violence. The processional approach adopted in this article focused on the spatial as well as the temporal dimension of how neighborhoods can be transformed. Doing this brings into sharp relief how ethnic composition, social networks, and location of the neighborhood all interact in space and over time. In unearthing how Angwan Rogo became progressively more segregated, I also uncovered how its social networks became increasingly intra-ethnic. Accordingly, as group relations deteriorated in Nasarawa Gwong, residents' associations and vigilantes became decentralized, and parallel networks emerged along ethnic lines.

On the basis of these notions, this article offers important conceptual tools for undertaking rigorous neighborhood-level analysis of ethnic violence. This approach has the potential for yielding insights that can serve to support or challenge ideas derived from macro-level studies. Furthermore, in clearly specifying the milestones involved in the processes of neighborhood transformation, it provides a viable basis for comparative analysis. For example, it raises the question of whether neighborhoods in other riot-prone cities reflect the socio-spatial characteristics of the stronghold and the frontier, and if they experience similar processes of transformation before the outbreak of major episodes of violence.

Tracing these processes of transformation has revealed how a neighborhood's ethnic composition and location can affect its evolution. Nasarawa Gwong's ethnic composition and its location between segregated settlements contributed to its transformation into a frontier. This insight has important implications for policy. It calls for peacebuilders to examine a neighborhood's location vis-à-vis adjoining neighborhoods and to respond in ways that consider group solidarity in the stronghold, multilevel competition and contestations in the frontier, and their developments over time.

Additionally, exploring the very events and processes that helped transform the neighborhoods has revealed possible strategies for managing conflict and mitigating violence. This exploration shines a light on milestones that mark strategic points for intervention. For example, it is clear that periods preceding elections are characterized by an increase in ethnic activism, and at these critical times violence is most likely to erupt. It is also clear that political appointments negatively impact social networks. This 
understanding can help authorities design context-sensitive proactive strategies for preventing violence. Such measures could include civic structures to monitor and check use of divisive rhetoric by politicians within neighborhoods during electoral campaigns.

This article is part of a preliminary step in exploring the spatial patterns of violence in a riot-ridden city. To further understand the concentration and persistence of violence in particular socio-spatial contexts, we need to zoom in on frontiers. Understanding in detail the causal mechanisms that make frontiers sites of persistent violence will, besides advancing knowledge on the dynamics of ethnic violence, contribute meaningfully to finding effective response to violent riots.

\section{Acknowledgments}

This article is based on field research conducted between 2014 and 2018. The researcher received funding from the European Union's Seventh Framework Programme (FP7/2007-2013) and further support from the Challenges to Democratic Representation program group of the Amsterdam Institute for Social Science Research (AISSR) and the Political Science department of the University of Amsterdam. I thank Floris Vermeulen, Walter Nicholls and Jean Tillie for their insightful contributions. I also thank the editors of African Studies Review and the reviewers who read the drafts and gave valuable feedback.

\section{References}

Abdullahi, Ali Arazeem, and L. Saka. 2007. "Ethno-Religious and Political Conflicts: Threat to Nigeria Nascent Democracy." Journal of Sustainable Development in Africa 9 (3): 21-36.

Adetula, Victor. 1992. "The Political Economy of Democratic Transition in Nigeria, 1985-1991." In Democratic Transition in Africa Ibadan, edited by Bernard Caron, Alex Gboyega, Eghosa E. Osaghae, 333-48. Nigeria: CREDU.

Anyanwu, Aham, ed. 1992. The Nigerian Structural Adjustment Programme: A MultiSectoral Analysis. ABIC Books \& Equipment, in conjunction with Avan Global Research Consult Abia State University, Nigeria.

Beckman, Björn. 1991. "Empowerment or Repression? The World Bank and the Politics of African Adjustment.” Africa Development/Afrique et Développement 16 (1): 45-72.

Berenschot, Ward. 2011. "The Spatial Distribution of Riots: Patronage and the Instigation of Communal Violence in Gujarat, India.” World Development 39 (2): 221-30.

Best, Shedrack Gaya. 2007. Conflict and Peace Building in Plateau State, Nigeria. Ibadan: Spectrum Books Limited.

Bhavnani, Ravi, Karsten Donnay, Dan Miodownik, Maayan Mor, and Dirk Helbing. 2014. "Group Segregation and Urban Violence." American Journal of Political Science 58 (1): 226-45.

Bou Akar, Hiba. 2012. “Contesting Beirut's Frontiers.” City E Society 24 (2): 150-72.

Brass, Paul. 2004. "Development of an Institutionalised Riot System in Meerut City, 1961 to 1982." Economic and Political Weekly 39 (44): 4839-848. 
Bunte, Jonas B. and Laura Thaut Vinson. 2016. "Local Power-Sharing Institutions and Interreligious Violence in Nigeria." Journal of Peace Research 53 (1): 49-65.

Collier, Paul, and Nicholas Sambanis, eds. 2005. Understanding Civil War: Volume 1, Africa. Washington, D.C.: World Bank Publications.

Cunningham, Niall. 2013. "The Doctrine of Vicarious Punishment: Space, Religion and the Belfast Troubles of 1920-22." Journal of Historical Geography 40: 52-66.

Danfulani, Umar Habila Dadem, and Sati Fwatshak. 2002. "Briefing: The September 2001 Events in Jos, Nigeria." African Affairs 101 (403): 243-55.

Dynes, Russel and Enrico L. Quarantelli. 1968. "What looting in civil disturbances really means." Trans-action 5 (6): 9-14.

Egwu, Samuel Gabriel. 2004. Ethnicity and Citizenship in Urban Nigeria: The Jos Case, 1960-2000. PhD. diss. University of Jos.

Ehrhardt, David. 2017. "Indigeneship, bureaucratic discretion, and institutional change in Northern Nigeria." African Affairs 116 (464): 462-83.

Elbadawi, E., and Nicholas Sambanis. 2000. "Why Are There So Many Civil Wars in Africa? Understanding and Preventing Violent Conflict." Journal of African Economies 9 (3): 24-69.

Fearon, James. 2006. "Ethnic Mobilization and Ethnic Violence." In The Oxford Handbook of Political Economy, edited by Donald A. Wittman and Barry R. Weingast, 852-68. New York: Oxford University Press.

Fourchard, Laurent. 2015. "Bureaucrats and Indigenes: Producing and Bypassing Certificates of Origin in Nigeria." Africa 85 (1): 37-58.

Gutiérrez-Sanín, Francisco, and Elizabeth Jean Wood. 2017. "What Should We Mean by 'Pattern of Political Violence'? Repertoire, Targeting, Frequency, and Technique." Perspectives on Politics 15 (1): 20-41.

—. 2014. "Variation in Violence by Paramilitary Groups in Colombia." Paper presented at the annual meeting of the American Political Science Association, Washington, D.C., August 29, 2014.

Higazi, Adam. 2011. The Jos Crisis: A Recurrent Nigerian Tragedy. Abuja: Friedrichebert-stiftung.

Human Rights Watch. 2001. Jos: A City Torn Apart. New York: Human Rights Watch. (accessed at http://www.hrw.org/sites/default/files/reports/nigeria1201_1. pdf on 5 June 2015).

-2009. Arbitrary Killings by Security Forces: Submission to the Investigative Bodies on the November 28-29, 2008 Violence in Jos, Plateau State, Nigeria. New York: Human Rights Watch. http://www.hrw.org/en/reports/2009/07/20/arbitrarykillings-security-forces-0.

Ihonvbere, Julius, and Eme Ekekwe. 1988. "Dependent Capitalism, Structural Adjustment and Democratic Possibilities in Nigeria's Third Republic." Africa Spectrum 23 (3): 273-91.

International Crisis Group. 2012. Curbing Violence in Nigeria (I): The Jos Crisis (accessed at https://www.crisisgroup.org/africa/west-africa/nigeria/curbing-violencenigeria-i-jos-crisis on 12 May 2016).

Jarman, Neil, and Chris O'Halloran. 2001. "Recreational Rioting: Young People, Interface Areas and Violence." Child Care in Practice 7 (1): 2-16.

Jega, Attahiru, ed. 2000. Identity Transformation and Identity Politics under Structural Adjustment in Nigeria. Kano: Nordic Africa Institute.

Kalyvas, Stathis. 2006. The Logic of Violence in Civil War. Cambridge, UK: Cambridge University Press. 
. 2012. "Micro-Level Studies of Violence in Civil War: Refining and Extending the Control-Collaboration Model." Terrorism and Political Violence 24 (4): 658-68.

Kitschelt, Herbert, and Steven Wilkinson, eds. 2007. Patrons, Clients and Policies: Patterns of Democratic Accountability and Political Competition. Cambridge, UK: Cambridge University Press.

Kotek, Joël. 1999. "Divided cities in the European cultural context." Progress in Planning 52 (3): 227-37.

Krause, Jana. 2011. "A Deadly Cycle: Ethno-religious Conflict in Jos, Plateau State, Nigeria." Working Paper. Geneva: Geneva Declaration Secretariat.

—. 2017. "Non-Violence and Civilian Agency in Communal War: Evidence from Jos, Nigeria.” African Affairs 116 (463): 261-83.

Kutmanaliev, Joldon. 2015. "Public and Communal Spaces and Their Relation to the Spatial Dynamics of Ethnic Riots: Violence and Non-Violence in the City of Osh.” International Journal of Sociology and Social Policy 35 (7/8): 449-77.

Legewie, Joscha and Merlin Schaeffer. 2016. "Contested Boundaries: Explaining Where Ethnoracial Diversity Provokes Neighborhood Conflict.” American Journal of Sociology 122 (1): 125-61.

Mac Ginty, Roger. 2004. "Looting in the context of violent conflict: A conceptualisation and typology." Third world quarterly 25 (5): 857-70.

Madueke, Kingsley. 2018a. "From Neighbours to Deadly Enemies: Excavating Landscapes of Territoriality and Ethnic Violence in Jos, Nigeria." Journal of Contemporary African Studies 36 (1): 87-102.

_. 2018b. "Routing Ethnic Violence in a Divided City: Walking in the Footsteps of Armed Mobs in Jos, Nigeria." The Journal of Modern African Studies 56 (3): 443-70.

Mesev, Victor, Peter Shirlow, and Joni Downs. 2009. "The Geography of Conflict and Death in Belfast, Northern Ireland." Annals of the Association of American Geographers 99 (5): 893-903.

Milligan, Maren. 2013. "Fighting for the Right to Exist: Institutions, Identity, and Conflict in Jos, Nigeria." Comparative Politics 45 (3): 313-34.

Mustapha, Abdul Raufu. 2000. "Transformation of Minority Identities in PostColonial Nigeria." In Identity Transformation and Identity Politics under Structural Adjustment in Nigeria, edited by Attahiru Jega, 86-108. Kano: Nordiska Afrikainstitutet, Uppsala in collaboration with The Centre for Research and Documentation.

Nagel, Joane. 1994. "Constructing Ethnicity: Creating and Recreating Ethnic Identity and Culture." Social Problems 41 (1): 152-76.

Nnoli, Okwudiba, ed. 1998. Ethnic Conflicts in Africa. African Books Collective. Dakar: CODESRIA.

Nyam, Ajiji David and Larab Tangshak Ayuba. 2016. "The growth of urban slums and conflicts in Nigeria: A case study of Jos and environs 1980-2010." International Journal of Social Science and Humanity 6 (5): 364.

Olzak, Susan. 1983. "Contemporary Ethnic Mobilization." Annual Review of Sociology 9 (1): $355-74$.

Osaghae, Eghosa. 1995. Structural Adjustment and Ethnicity in Nigeria. Uppsala: Nordic Africa Institute.

Ostien, Philip. 2009. "Jonah Jang and the Jasawa: Ethno-Religious Conflict in Jos, Nigeria." Muslim-Christian Relations in Africa.

Rodgers, Dennis. 2004. "Disembedding' the City: Crime, Insecurity and Spatial Organization in Managua, Nicaragua.” Environment and Urbanization 16 (2): 113-24. 
Sambanis, Nicholas. 2001. "Do Ethnic and Nonethnic Civil Wars Have the Same Causes? A Theoretical and Empirical Inquiry (part 1)." Journal of Conflict Resolution 45 (3): 259-82.

Sayne, Aaron. 2012. Rethinking Nigeria's Indigene-Settler Conflicts. Washington, D.C.: United States Institute of Peace.

Scacco, Alexandra. 2012. Anatomy of a Riot: Participation in Ethnic Violence in Nigeria. New York: New York University.

Sesay, Amadu, and Charles Ukeje. 2009. Post-War Regimes and State Reconstruction in Liberia and Sierra Leone. African Books Collective. Dakar: CODESRIA.

Tilly, Charles. 2000. "Spaces of Contention.” Mobilization: An International Quarterly 5 (2): 135-59.

- 2003. The Politics of Collective Violence. Cambridge: Cambridge University Press. Varshney, Ashutosh. 2001. "Ethnic Conflict and Civil Society: India and Beyond." World Politics 53 (3): 362-98.

Vlassenroot, Koen. 2002. "Citizenship, Identity Formation \& Conflict in South Kivu: The Case of the Banyamulenge." Review of African Political Economy 29 (93-94): 499-516.

Weidmann, Nils, 2009. "Geography as motivation and opportunity: Group concentration and ethnic conflict.” Journal of Conflict Resolution 53 (4): 526-43.

Wilkinson, Steven. 2006. Votes and Violence: Electoral Competition and Ethnic Riots in India. Cambridge, UK: Cambridge University Press.

Williams, Paul. 2004. "Peace Operations and the International Financial Institutions: Insights from Rwanda and Sierra Leone.” International Peacekeeping 11 (1): 103-23.

\section{Notes}

1. Actual number of deaths is unknown but conservative estimates range between 4,000 and 7,000 (see Higazi 2011:18; Krause 2011:12); In my mind, a reasonable estimate for deaths caused by violence within Jos and environs between 2001 and 2010 is 5,000 .

2. Visits and discussions with residents of Angwan Rogo, February 2016.

3. The All Nigeria Peoples Party (ANPP) merged with two other political parties in 2013 to form the Action People's Congress (APC), which is heavily supported by Muslims in Jos and northern Nigeria. It won the 2015 general election against the ruling People's Democratic Party (PDP). See "Youth Set Ablaze PDP Chieftain House," Premium Times March 19, 2015; http://www.premiumtimesng.com/ regional/north-central/179993-breaking-youth-set-ablaze-pdp-leaders-house.html.

4. Interview with former resident of Angwan Rogo, March 12, 2017.

5. Interview with security officer, May 1, 2012.

6. Discussions with pickup driver in Bukuru, May 18, 2017.

7. Discussions at Bauchi Road Motorpark near Angwan Rogo, May 19, 2017.

8. Interview with resident of Angwan Rogo, February 13, 2017.

9. Interview with resident of Angwan Rogo, March 12, 2017.

10. Interview with former resident of Kabong, February 18, 2017.

11. Interview with resident, May 17, 2017.

12. Interview with local politician, May 18, 2017.

13. Interview with former resident, April 14, 2016.

14. Interview with politician in Jos, April 21, 2017.

15. Interview with politician in Jos, March 17, 2017. 
16. Justice Bola Ajibola Reports of the Judicial Commission of Enquiry into the Jos Unrest of 28 November 2008, Volume 1 Main Report, October 2009, 68.

17. The indigene certificate is issued by LGA authorities to differentiate between indigenes and the migrants or settlers. It lets individuals benefit from scholarships, school admissions, employment quotas, and tenured positions as heads of government ministries and agencies.

18. Discussions with residents, May 18, 2016.

19. Interview with NGO representative, July 13, 2012.

20. At this point in time, this was a rumor lacking government substantiation. The rumor later proved to have some truth when Jonah Jang, who assumed office as governor of Plateau State in 2007, initiated plans to implement the Jos Master Plan, an urban renewal project that sought to remove and relocated some sections of the city's populations.

21. Interview with resident, April 17, 2016.

22. Interview with former neighborhood leader, May 13, 2016.

23. Interview with neighborhood leader, March 27, 2017.

24. Interviews with residents, March 14-15, 2016.

25. Interview with resident, May 17, 2017.

26. Interview with party official, May 17, 2017.

27. Interview with self-proclaimed political activist, March 18, 2017.

28. Interview with local politician, May 17, 2017.

29. Interview with resident of Nasarawa Gwong, May 16, 2017.

30. Election results were provided by Independent National Electoral Commission (INEC) and Plateau State Independent Electoral Commission (PLASIEC) in Jos, Plateau State.

31. See Niki Tobi White Paper on the report of the judicial commission of enquiry into the civil disturbances in Jos and its environs, September 2002, 50-51.

32. Interviews in Nasarawa Gwong, April 13, 2016.

33. Interview in Filin Ball, April 13, 2016.

34. Versions of the story vary but all of them suggest there was an altercation between a group of Muslims and a Christian woman.

35. Discussions with a cross section of residents in Nasarawa Gwong, April, 14, 2016.

36. Interview with resident, April 17, 2016.

37. Interview with youth leader in Congo-Russia, March 11, 2016. 